Received 5 December 2019; accepted 3 April 2020.

Available online 30 April 2020

\title{
Integration between Torrent Protection Gray Infrastructures with Constructed Wetland to Achieve Resilience in Ras Gharib Ahmed Haron
}

MTI University, Faculty of Engineering, Cairo, Egypt

Archharon@gmail.com

\begin{abstract}
Flooding and torrents are a seasonal phenomenon that hit a lot of cities every year around the world. As climate changes affect the world, cities are increasingly exposed to such threats especially those located on flood streams are most exposed to damages in the winter and the flooding season. In the past ten years, Egypt has been facing severe climate change effects like the increasing frequency of flooding in Egyptian cities. According to the Egyptian government, there are more than 1200 Egyptian cities and villages on flood streams and torrent tracks. These cities are distributed between the Mediterranean coast, Cairo region, Red Sea coast, Sinai and Upper Egypt, these and increasingly vulnerable towards the floods and their urban life is severely affected weather in old cities or in new planned cities. It is mostly located in the Eastern Desert at the east of the Nile. According to geologists and Meteorologists, these cities and their inhabitants are facing future hazards if they were not well prepared to handle floods. The international experience in constructed wetland projects proved to be a successful technique maintaining floods and turning it into sources of development and increasing biodiversity. Several countries led by China have developed national strategies to use wetland parks as a defense tool against flood risks, at the same time these parks have become a source of income for their cities. This paper is a part of series of papers and researches for constructed wetland technology and opportunities to use it in Egypt.

In this paper, the torrents and flood risks facing Ras Gharib city will be highlighted. Explaining the abilities of constructed wetland parks to minimize the damage and transform it into a source of strength, which will be a part of resilience city new policies. The research method is a comparative analysis between international project strategies and the Egyptian current strategies and actions to face flood and torrent risk. It will be the fundamentals of an Egyptian model that is compatible with the city's risks and challenges.
\end{abstract}

\section{KEYWORDS}

Constructed Wetland-Infrastructure -Egypt - Flashfloods- Ras gharib

\section{INTRODUCTION}

Climatic changes caused torrential rains to increase in the Egyptian cities and villages. This resulted in hundreds of deaths and thousands of injuries in the last 10 years, according to Egyptian government data (Mohamed Abd El- Rahman and Others 2013, Akram ElGanzori 2012 and EEAA2016). This led to the destruction of many homes, the flooding of villages, and the destruction of roads and infrastructure. In 2016 Ras Gharib faced the worst torrents and the heaviest rainfall for decades. This catastrophe caused the demolition of many houses, the death of more than 8 people, and the displacement of thousands, in addition to losing thousands of livestock. Also, the city infrastructure was affected by blackouts and water outages and road network collapses. This led to the thinking and planning of many methods of rain protection. 
With the support of the central government, a plan has been drawn up to implement mega protection projects such as dams and artificial lakes to contain rainwater.

In conjunction with the torrential rain and rain crisis, Egypt faces the risk of water poverty, which increases year by year, due to climatic, political and demographic reasons. To face this existential threat, projects and research have emerged that work to reuse water in various fields. The government and researchers have increased their focus on designing and implementing water management projects to achieve the highest efficiency in water use and rationalization.

In light of these challenges and problems, one of the most important current concepts of urban development must appear which the resilience city is. It is defined as its resisting, accommodating and recovering capability from risk effects in a timely and efficient manner. In cities' planning context it's introduced as a new model for urbanization and affects the way of our understanding and the management of urban planning and hazards on the urban level as well. In this concept, risks are dealt with as an unguarded power element that must be contained and transformed into a source and an engine for development. So that cities prepare for disasters and cope with them during the disaster and recover from them more quickly and without achieving losses and in some cases achieving physical, material and social gains.

The technology of constructed wetlands is one of the methods which could be used as a transition from gray to green infrastructure. Also, it is being a method of dealing with floods and floods and achieves an economic and urban return in the medium and long term (Josh Foster and others, 2011). Using this technique in Egypt is still limited despite its spread in many countries around the world and has proven effective results.

\section{GREEN INFRASTRUCTURE CONCEPT AND APPLICATIONS}

Green infrastructure defined it (Friedrich Olmsted, 1880) as" the interconnected network of open spaces. And natural that includes green areas, and lands Rainwater drains naturally and reduces flood risk, collects and collects pollutants, and improves quality Water. Green infrastructure, parks and reserves, public and domestic parks, flood streams, Green surfaces in streets, public streets, pedestrian paths, public squares, roofs of buildings and walls Live, sports fields and finally cemeteries."( Hannah Wrigh , 2011) Also, United State Environmental agency EPA defined it as "...the range of measures that use plant or soil systems, permeable pavement or other permeable surfaces or substrates, stormwater harvest and reuse, or landscaping to store, infiltrate, or evapotranspiration stormwater and reduce flows to sewer systems or to surface waters." That is according to Section 502 of the Clean Water Act (US EPA, 2019) many definitions around the same concepts. These definitions changes related to application, time and use. Could summaries main applications of green infrastructure:

- Rainwater Harvesting

- Rain Gardens

- Planter Boxes

- Bioswales

- Green Streets and Alleys 
- Constructed Wetlands

- Green Roofs

- Urban Tree Canopy

This research will focus on constructed wetlands as a green infrastructure application in the arid area. Integrate it with gray infrastructure toward creating a resilient comprehensive system against water flooding, torrent, and heavy rainfall.

\section{CONSTRUCTED WETLAND}

Constructed wetlands are considered as man-made technologies that imitate the natural system of a wetland. These technologies have spread in the world to restore the balance between the natural environment and the built environment in cities (Hammer, 1992). And harvest the environmental, economic and social benefits out of them. Constructed wetlands have developed to solve urging issues like water filtration like Shanghai world expo park or food production like Shenyang Jianzhu University park (KongjianYu, 2015), Bahr El Baqar constructed wetland farm(Sohair I. AbouElela,2017), or as a part of the city green infrastructure like in Thailand and New Zealand (Marijke Ronduite, 2017) fig (1), or as a defense mechanism for the city against natural disasters like new York ( $\mathrm{CH} 2 \mathrm{M}$ Hill,2015) project. In addition, they have been turned into a successful economic driven tool as tourist attractions and ecological destinations which achieve a multifunction aspect of them.

Constructed wetland parks are considered economically feasible projects that contribute to the urban development goals as (Shanghai -Sydney) projects. These type of projects were well received and applied in tropical and wet climate conditions and even more, they were recently applied in arid and semiarid regions of the world like Wadi Hanifa project in Saudi Arabia that have received the Aga khan award in 2000 and Waset wetlands project in The united Arab of Emarits that have also received the Aga Khan award in 2019 (Aga Khan 2019)

Figure (1) Constructed wetland examples in China
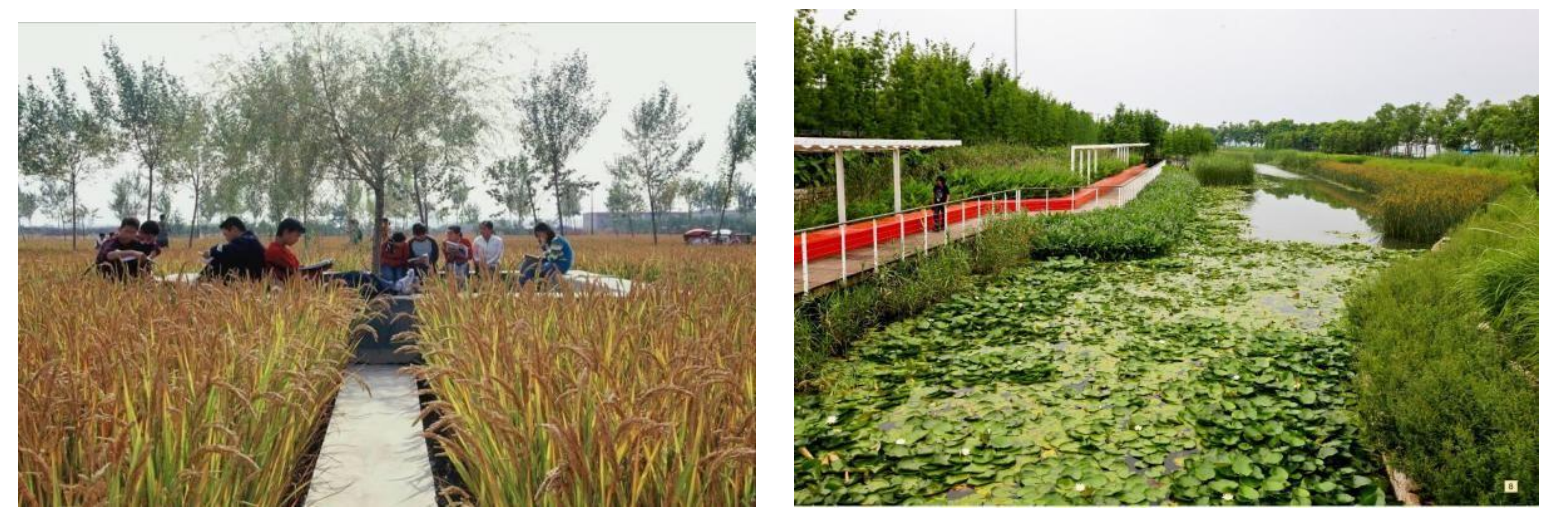

Source: https://www.turenscape.com/en/project/index/4.html

\section{CONSTRUCTED WETLAND PARKS VALUES}

The values that constructed wetland parks offer in the urban environment could be environmental, economic and social. These values are defined according to the project scale, type, and purpose of existing. 
Table (1) shows constructed wetland park's significant values and indicators for determining (sustainable) use of multi-function landscape services.

\begin{tabular}{|c|c|c|}
\hline Services & $\begin{array}{l}\text { Ecological process and/or } \\
\text { component providing the service }\end{array}$ & $\begin{array}{l}\text { Performance indicator (how much can } \\
\text { be used/provided in sustainable way) }\end{array}$ \\
\hline Water treatment & $\begin{array}{l}\text { Role of wetland pathogens in } \\
\text { wastewater treatment }\end{array}$ & $\begin{array}{l}\text { Max amount of chemicals and } \\
\text { pollutants that can be recycled or } \\
\text { immobilized on a sustainable basis. }\end{array}$ \\
\hline $\begin{array}{l}\text { Air quality regulation: } \\
\text { (e.g. capturing dust } \\
\text { particles) }\end{array}$ & $\begin{array}{l}\text { The capacity of the urban landscape } \\
\text { to extract aerosols \& chemicals from } \\
\text { the atmosphere }\end{array}$ & $\begin{array}{l}\text { Amount of aerosols or chemicals } \\
\text { "extracted"-effect on air quality }\end{array}$ \\
\hline $\begin{array}{l}\text { Provision of productive } \\
\text { plants, crops, } \\
\text { flowers...etc. }\end{array}$ & $\begin{array}{l}\text { Presence of edible plants and } \\
\text { productive crops. }\end{array}$ & $\begin{array}{l}\text { Net Productivity } \\
\text { (in } \mathrm{kg} / \mathrm{ha} / \text { year or other units) }\end{array}$ \\
\hline Climate Regulation & $\begin{array}{l}\text { Influence of the project on local } \\
\text { climate through land-cover and } \\
\text { biologically-mediated processes }\end{array}$ & $\begin{array}{l}\text { Quantity of Greenhouse } \\
\text { gases, etc. fixed and/or emitted Effect } \\
\text { on climate parameters }\end{array}$ \\
\hline Gene pool protection & $\begin{array}{l}\text { Maintenance of a given ecological } \\
\text { balance and evolutionary processes }\end{array}$ & $\begin{array}{l}\text { "Ecological Value" (i.e. } \\
\text { difference between actual and } \\
\text { potential biodiversity value) } \\
\text { Cultural \& amenity }\end{array}$ \\
\hline Aesthetic values & $\begin{array}{l}\text { The aesthetic quality of the } \\
\text { landscape, } \\
\text { based on e.g. structural diversity, } \\
\text { "greenness", tranquility }\end{array}$ & $\begin{array}{l}\text { Expressed aesthetic value, } \\
\text { e.g.: Number of users of "scenic routes' }\end{array}$ \\
\hline Recreational values & $\begin{array}{l}\text { Opportunities for tourism and } \\
\text { recreational activities }\end{array}$ & $\begin{array}{l}\text { Number/area of landscape } \& \text { wildlife } \\
\text { features with stated recreational value }\end{array}$ \\
\hline $\begin{array}{l}\text { Education \& science } \\
\text { opportunities for } \\
\text { formal/informal } \\
\text { education \& training }\end{array}$ & $\begin{array}{l}\text { Features with special educational } \\
\text { and scientific value/interest }\end{array}$ & $\begin{array}{l}\text { The number of scientific studies, } \\
\text { academic research papers, scientific } \\
\text { dissertations.....etc. }\end{array}$ \\
\hline Economical value & $\begin{array}{l}\text { The reduced implementation and } \\
\text { operating cost of the multi-function } \\
\text { landscape project }\end{array}$ & $\begin{array}{l}\text { The difference in construction, water } \\
\text { treatment, and operating costs } \\
\text { between the proposed project and } \\
\text { similar mechanical methods }\end{array}$ \\
\hline
\end{tabular}

Source: adapted from: (R.S. de Groot et al. 2010), Edited by Rash Gaber, Ahmed Haron, 2018

\subsection{Constructed Wetland and Flood Risk}

Using constructed wetlands to manage floods and runoff water has been a trending method used in many countries and in particular that in South East Asia for its many environmental benefits and how cost-efficient it is compared to other measures. The outcomes of a 
constructed wetland range from being a source of biodiversity to the ability to filtrate and recycle water. Constructed wetlands projects are considered as a resilient way to overcome seasonal extreme weather conditions and storm events that could be turned into hazards threatening these cities and their inhabitants (D.P.L. Rousseau and others,2008). Figure (2) shows examples of such projects that overcome the flood

Figure (2) Minghu Wetland Park, China

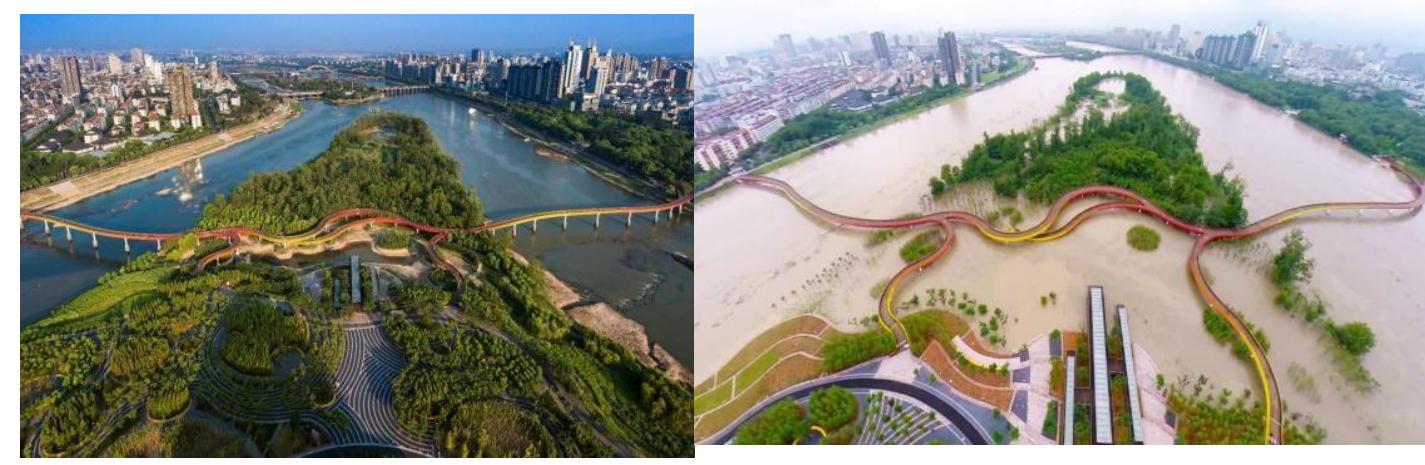

Source: Arch Daily 2015 https://www.archdaily.com/590066/minghu-wetland-parkingturenscape

constructed wetlands to harvest rainwater is not only economically viable in the construction phase, but also the cost of operation and maintenance in the long term compared to gray infrastructure is reduced. In the case of combining the gray infrastructure with green infrastructure by the integration of artificial green lands (Josh Foster and others, 2011) that makes it more efficient and expand its capacity when it comes to operation. The best example of integrating green with gray especially by constructed wetlands is the New York resilient city plan after the destructive Hurricane Sandy that affected the city in 2002, it adopted green strategies and the main mission was to integrate gray with green to be prepared for future hazards. In china the sponge city plan was adopted by the central government to face flood hazards in different Chinese cities that face the flood risks every year by also applying green strategies and projects to mitigate flood risks (Faith Ka Shun Chana and others 2018) and act as a source of attraction for these cities like the colorful bridge wetland project in Minghu Wetland Park. That became an all-year tourist attraction with changing scenes in each season according to the flood and water level in the river. In 2000 constructed wetlands approaches were used in the Arab region and North Africa showing high economic viability like the Wadi Hanifa project in Saudi Arabia that is a multifunctional and Bahr el-Baqar project in Egypt that was used in agriculture irrigation and water recycling.

Figure (3) Baher El Bakar Wetland aerial view in 2006 and 2016

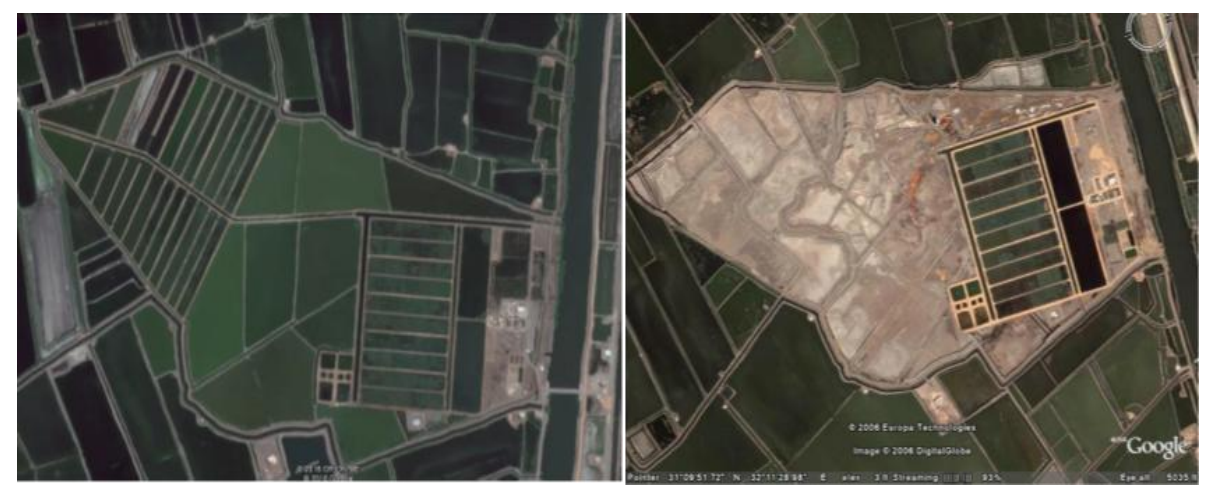


Source: Ahmed Ali Rashed (2017)

\section{INTERNATIONAL CASE STUDY}

In this part of the research, we will highlight international constructed wetland projects in an arid area, studding policies framework, values, and challenges.

\subsection{Case Studies Criteria}

Case studies were chosen according to specific criteria and a set of factors as the following;

- The city is exposed to climate changes, floods/ torrent / heavy rain, and seasonal hazards

- A city that shares the same characteristics and climatic conditions with the Egyptian case study

- The green infrastructure is integrated with gray infrastructure

- The project is within or near to urban community and urban environment

o The case study has shown positive economic outcomes

\subsection{Wadi Hanifa, Saudi Arabia}

Wadi Hanifa is one of the main valleys in Saudi Arabia. It is a very important natural icon in the Najed plateau. The altitude of the plateau between 7000 to 1500 meters above sea level and it's located in the center of the Arabian Peninsula. Wadi Hanifa is represented as a natural wide area and drain path for surface water (Abdulaziz 2007). The valley passes through the capital of Saudi Arabia (Al Riyadh), it is a unique ecological site with $120 \mathrm{~km}$ long. That valley eastern sloped from Tuwige mountains to the desert area on southeast of Riyadh City.

The main valley flood canal is located east of the catchment area and water flows near Riyadh City. The watershed area is estimated at about $4400 \mathrm{~km}^{2}$ in 2007. last centuries Wadi Hanifa watershed ecosystem played the main role in communities' leaves on the valley, providing all-natural resources and make the balance in that unique system. After 80's the rapid growth of Riyadh affected the groundwater level, environment balance that is led to changes in the ecosystem and much environmental damage.

Figure (4) Wadi Hanifa and Al Riyadh City,
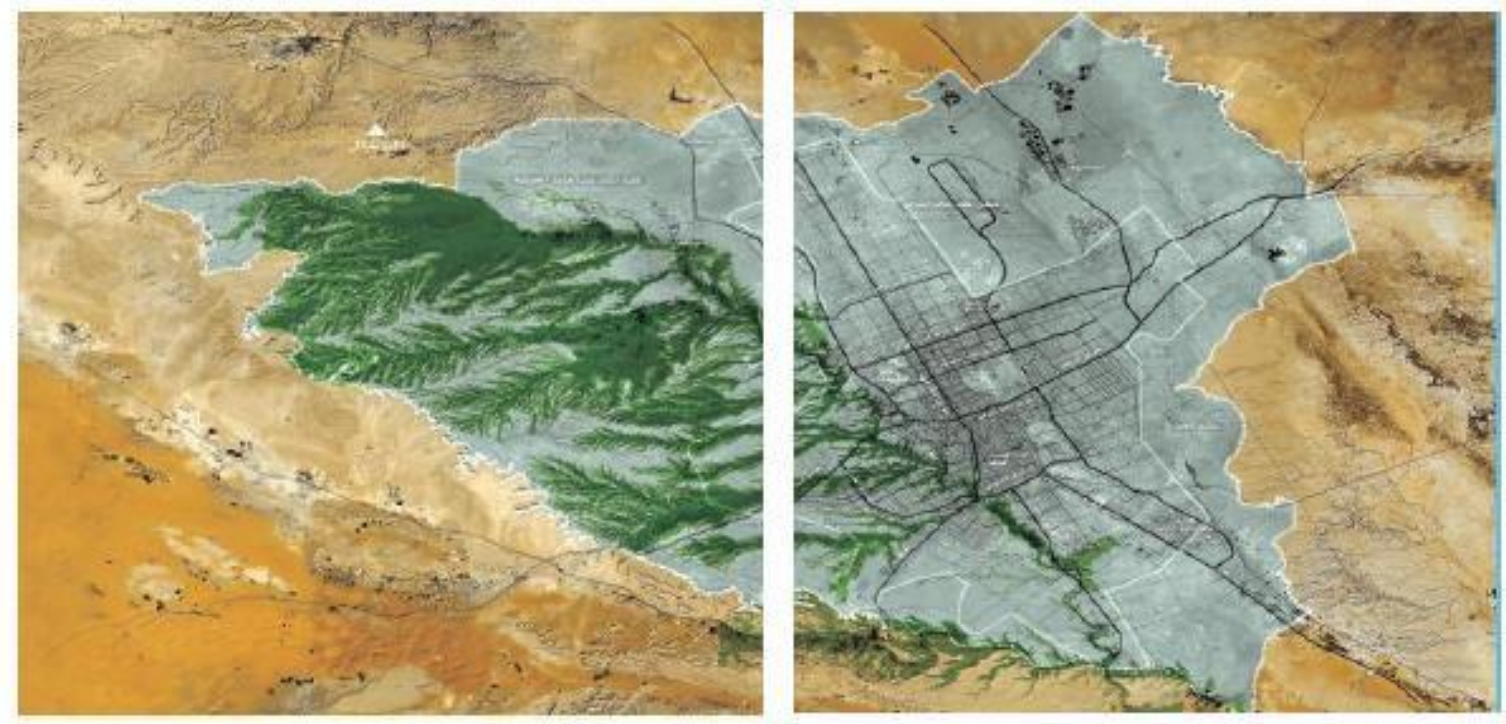

Source: Aga Khan 2019 
At 2001 Al Riyadh Development Authority started a new strategic plan for Wadi Hanif with cooperation from British firm Buro Happold and Candian Landscape Architecture firm Moriyama \& Teshima. That plan's main objectives enhancing Wadi Hanifa Environment, Tourist and recreational resources. Strategic plan divided into two parts Wadi Hanifa Development Program (WHDP) and Wadi Hanifa Restoration Project (WHRP). That project mainly focused on water quality, flood performance. WHDP focuses on gray infrastructure and landscape construction works.

\subsubsection{Project concept}

The main vision of the project is transforming the problems and challenges of the valley into a new opportunity. That's led the designers to make a slogan for the design "living Wadi ". Reviving the pure and nature valley including green areas, clean water, health, and safe environment and new destination Public Park. On its macro scale, the strategy of that project was integrating a wide range of landscape architecture, from master planning to landscaping, from architecture to signage and urban furniture. Living valley project aims at sustaining and protecting the environment and turns it into a powerful component of the area.fig No (5) shows the large-scale impact of the living valley.

Figure (5) Wadi Hanifa Large scale impact,
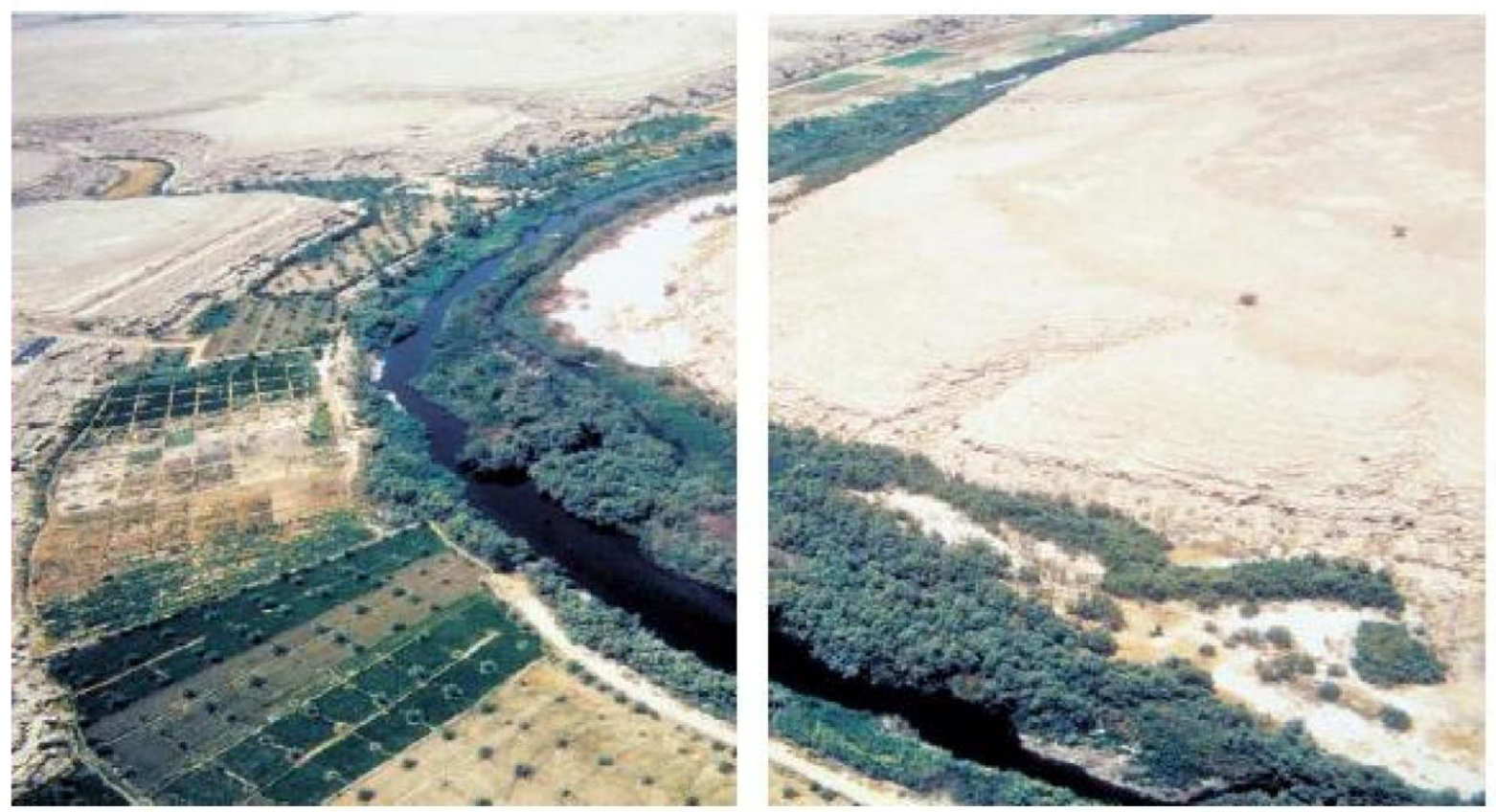

\subsubsection{Gray and Green Infrastructure}

The integration between the gray infrastructure represented in building al Ha'ir new dam and linking it with development in the valley, as fig (6) shows 
Figure (6) The integration between the gray infrastructure represented in building al $\mathrm{Ha}$ 'ir new dam

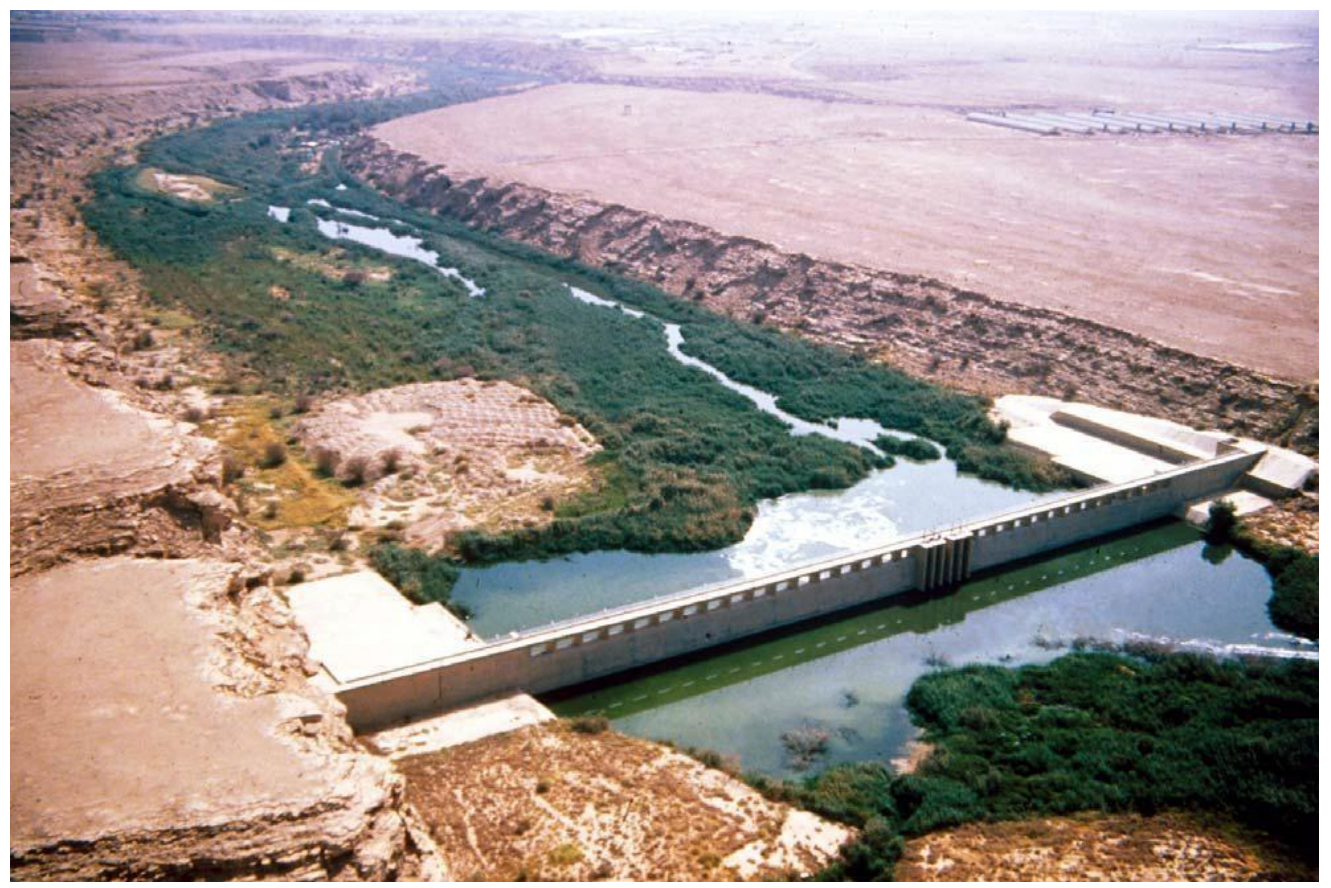

\subsubsection{Landscape-scale}

Gradually, the valley areas turned into tourist attractions to suit the desert nature of the region. This led to the establishment of parks that suit the cultural nature of Saudi society. Where there are areas of families with more privacy, areas to interact with nature, barbecue places and shaded areas along the park as fig (7) show.

At the design level, the geographical nature of the place and the geological formation have been used as a major component of the path design. In addition to using local plants, trees, and palm trees as part of the environmental system. Using stones and natural materials as part of the design and as a tool to control the speed of water to achieve the highest level of water purification, as the picture shows.

Figure (7) Social Areas and families activities
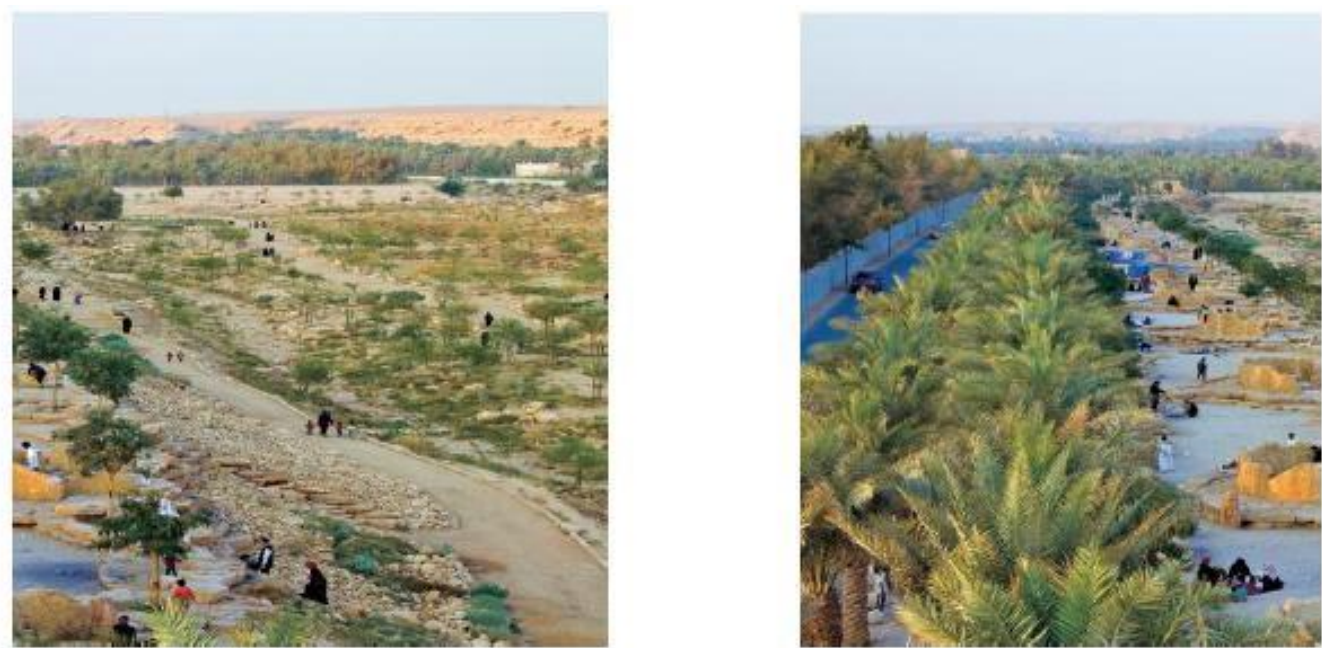


\subsubsection{Socio-Economic Value}

On the economic level, besides the agricultural revenue from the use of clean water, which is rare in the Arabian Peninsula, there has become fish production in the lakes and fish farms surrounding the valley that have benefited from the pure water and the sustainability of its presence due to the construction of the dam.

The Valley project represents a model for the integration of gray infrastructure with green infrastructure to achieve multiple goals leading to resource sustainability and integrated development for the region. That result of integrated planning and distinctive design commensurate with the nature found in this desert region, which led to the project to create a distinct character from other projects because of its deep connection to the localization at all levels of environmental, urban and social contexts.

\subsection{Urrbrae Wetland}

Urrbrae Wetland is a constructed wetland, located in the center of the suburban of Mitcham. It aims to reshape land cover, wildlife, and biodiversity of the area prior to European settlement, in 1836. Native fauna and flora and have been carefully managed by high environmental sensitive programs. While Urrbrae wetland only covers an area of approximately $25200 \mathrm{~m} 2$, its catchment area is around 380 hectares fig (8), along with many different pollutants. Before establishing the Urrbrae Wetlands the water and its pollutants flooded local areas, before flowing into the Brown Creek Catchment, the Patawolunga then out into the Gulf of St Vincent.

\subsubsection{Project concept}

The multifunctional objective plan made for Urrbrae Wetland includes the cleansing of the stormwater by Filtering out large debris through the trash racks, using slow flow to achieve sedimentation. Removing heavy metals, salts, and bacteria by sticking onto the falling particles, this is called flocculation. Reeds, sedges and plants that make up the riparian zone filter out a lot of salts and heavy metals.

\subsubsection{Gray and green infrastructure}

Integration between Drainage rain networks along 380 hectares as shown in fig (8).

Creating a farm dam with a newly constructed wetland is a success story of combining between gray and green infrastructure

Figure (8) Urrbra Wetland Border scale and water catchment network
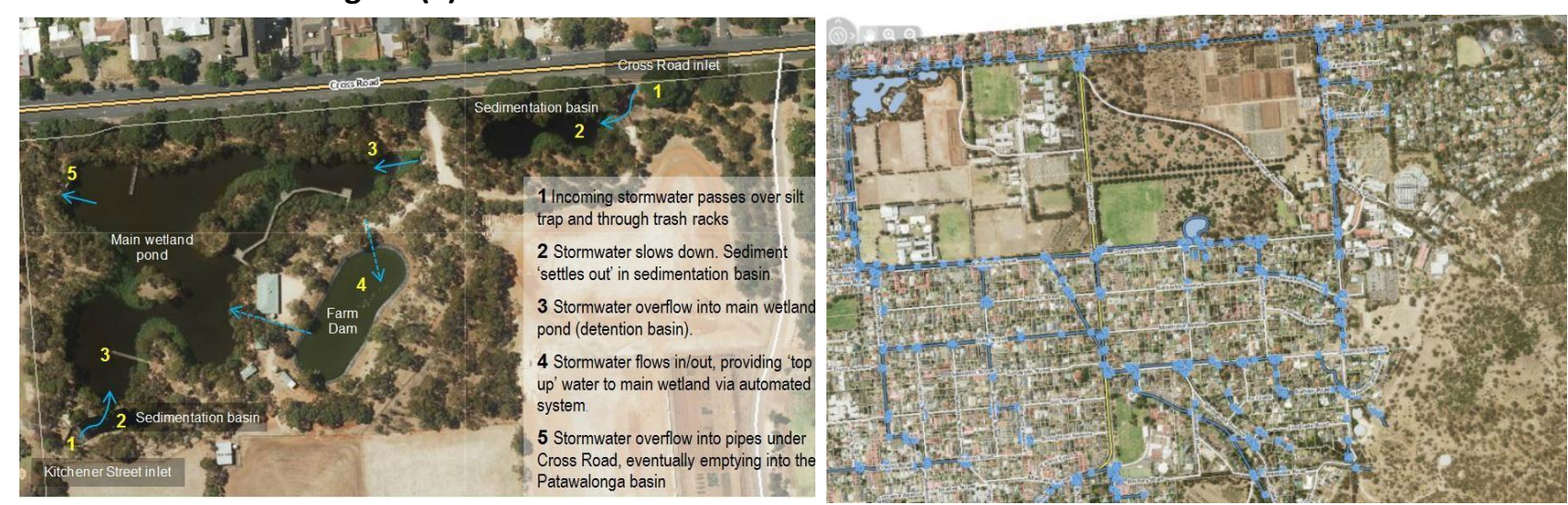

Source: http://www.urrbraewetlandlc.org/data-photos-and-maps.html 


\subsubsection{Landscape Scale}

In 2010 reports Constructed wetland could be able to prevent up to 17.7 million liters of floodwater/ year Provides an aquatic habitat. Park wetland has been planted with many different species of local plants. That provided habitats for various species of birds, animals, reptiles, amphibians, and macroinvertebrates. These habitats vary along with the project due to many factors including water flow, topography, soils, and human impacts.

Freshwater habitats are divided into three main zones according to design and location.

1. Inland Zone - grey box grassy woodland

2. Riparian Zone - terrestrial meets aquatic 3. In-stream Zone - in the water the vegetation types present at the Wetland not only provide habitat for native animals but help slow the speed of the water which aids the sedimentation process. Many of the riparian and in-stream plants are able to absorb substances including nitrates and phosphates, thus removing them from the water. The distinct habitat zone also provides a valuable resource for conducting controlled experiments to discover preferred habitat types fig (9).

\subsubsection{Socio-Economic Value}

The Urrbrae Wetland offers a unique and engaging learning chance for a different level of age with an interactive and live education environment. More than 6000 visitors/year on average, 5500 students and 1500 tourists according to the 2014 report. The total construction cost of the project 1.7 million Australian dollars in two stages. The project economic ability 380 million liters of stormwater enters the wetland each year (long term average). 14.6 million Liters stormwater reserving capacity. 10 million liters capacity of clay-lined, 3 million liters capacity of synthetic lined Farm Dam.

Figure (9) Urrbrae Wetland vegetation zones

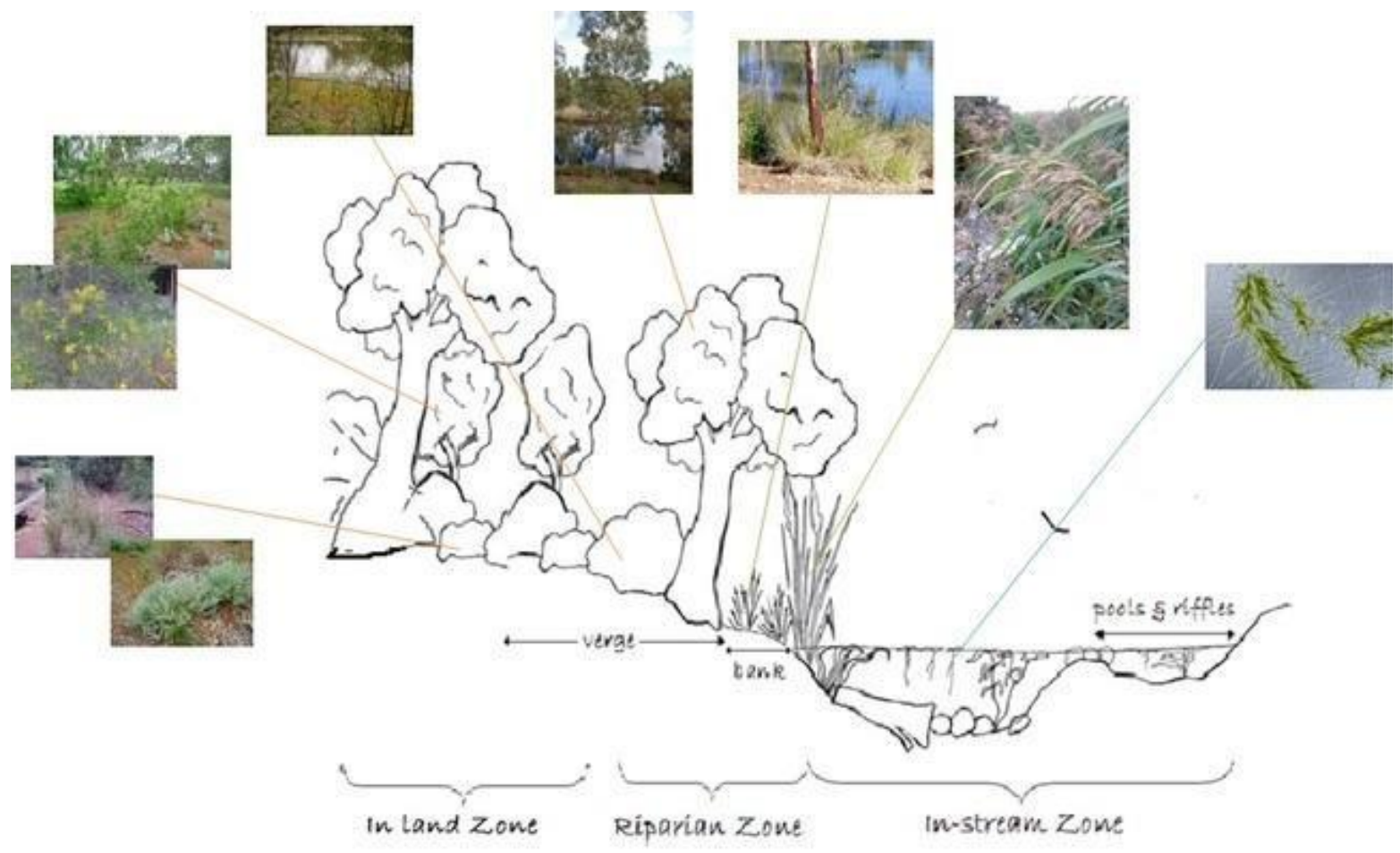


The project experience represents a new expression of the accumulation and multiplicity of functions resulting from the use of constructed wetlands. This functional and spatial diversity led to the sustainability of the project and its transformation from a seasonal need project to a permanent multiproject that benefits the city and society.

\subsection{Lessons Learned from International Cases}

Constructed wetland technology is low-cost technology with a high economic impact in the mid and long term. This technology can be integrated with existing or developed gray infrastructure. The possibility of diversification of project scales according to the needs of the region according to the water source. Many social and economic activities in addition to the environmental return could be achieved according to the project design, the region's needs, and the threat rates. The integration between the urban and environmental design in addition to the landscape with gray infrastructure designs achieves high results in the case of future planning. Investing in this technology achieves an investment return within five to ten years, which is a short period compared to investing in gray infrastructure.

\section{CASE STUDY: RAS GHARIB}

In 1937 the city of Ras Gharib city was founded after discovering the first oil field and was named after the mountain of (Ghareb) that is located near to the region with 1750 in height, located directly on the red sea coast within the eastern desert of Egypt. Located between latitudes 27_450 and 28_450 N and longitude 32_000 and 33_300E the city is estimated to be $10,464 \mathrm{~km} 2$ in area and considered to be the second-largest city in the Red Sea governorate (Hesham Ezz and others 2019).

Figure (10) Ras Gharib Layout

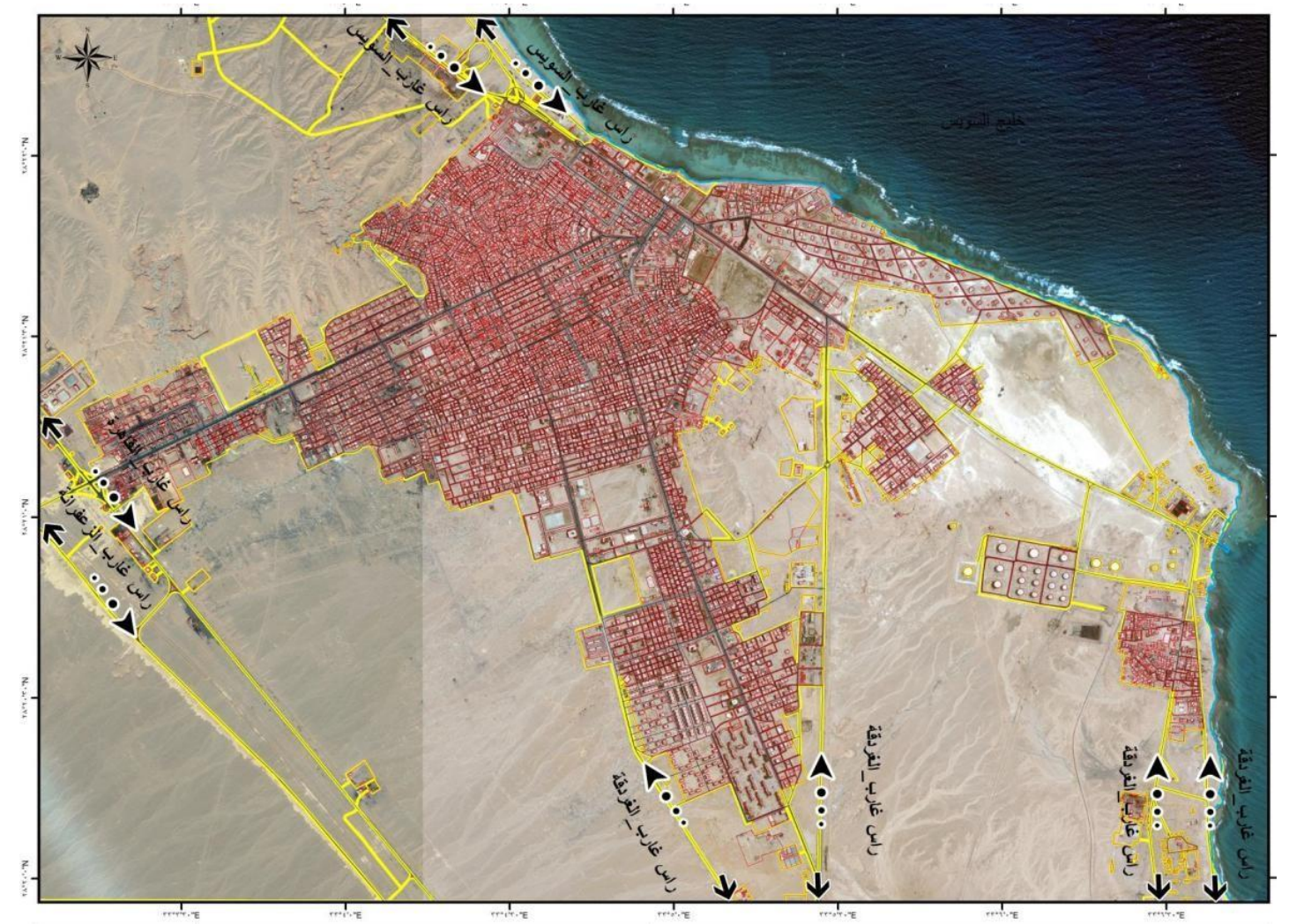

Source: Ahmed Serwa and Gehan Bayoumy, 2017 
The city is connected to the coastal red sea highway (Suez-Herdaga) and is linked to Suez city in the north and Hergada city with road networks stretching along the coast through the eastern desert and to the Nile valley region with Ras GharibSheihk Fadl road. (Mahmod A., Abdel Hamid A.,2015). the population count is almost 60000 inhabitants.

\subsection{City Context}

\subsubsection{Urban context}

It's considered one of the lowest density cities in the red sea governorate Red Sea Gov 2019). 8,989 buildings present the total building's number at the city according to the 2017 report 7,539 residential building, 481 commercial and 366 other activities.

\subsubsection{Socio-Economic Context}

Ras Gharib population 41,526 according to 2017.whil the population was almost 60,000 people in 2014. Population indicator changing that means the city was the city is among the golden triangle project set to develop the region between Upper Egypt along with the Nile and the eastern gate of Egypt on the red sea across the mountains of the eastern desert(Azza Sirry 2018)

And it is responsible for $67 \%$ of Egypt oil reserve and is one of Egypt's main resources of petroleum products and oil industry, the main economic activity is related to that with logistics of oil transferring and extracting activities, The mountain topography allowed some other activities like the extraction of Industrial minerals and rocks such as kaolin, glass sand, quartz, feldspar, marble, and other materials. In the government development plan, the city is planned to be a key point for petroleum services and touristic activities, in addition, it's considered a great potential location for generating wind energy.

Figure (11) Urban development strategy of waterfronts, red sea

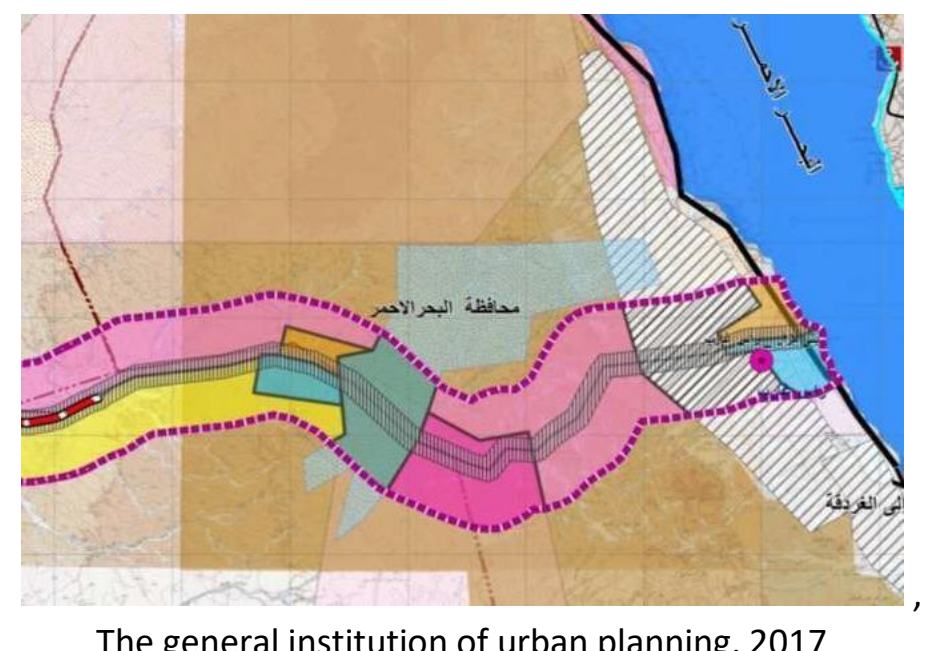

The general institution of urban planning, 2017

\subsubsection{Environment context}

The climate of Ras Gharib city is typically arid and semi-arid following the climate of eastern desert, the rainfall perception is very low, it's estimated that the rain period 
is eleven days in total per year and when the rainfall exceeds $50 \mathrm{~mm}$ it causes flash floods hazards however climate change in the past five decades led to the growing frequency of flash floods hazards threatening the city every year. (Mohammed Sadek and Xuxiang $L$ (2019)

- According to the topographical nature of the eastern desert, the city area is divided into two zones; west zone of the city include mountains with steep slops towards the east coastal zone where the terrain slope changes between 0 t0 $300 \mathrm{~m}$ above sea level (Youssef and M. A. Hegab, 2005)

- According to (Hegazy \& Effat, 2010) there is a various rock formation inland terrain due to the mountainous nature of the area and further to the east salt deposits accumulate and mostly sand, gravel and sandstone exist.

\subsection{Flood risk story}

Flash floods hit the region each time from once to twice seasonally due to the wadi systems that drain the water either towards the Nile valley or towards the eastern desert (Mohammed El Bastawesy and others 2009) The city is situated opposite to nine Wadi systems and their drainage basins Created from the mountains series in the west integrating with it and crossing connecting roads. In case of heavy rainfall, the flooding flow from west to east reaching drainage basins and ending into the Suez Golf coast these drainage basins are named from north to south Wadi Abu Had; Wadi El-Darb; Wadi El-Khareim; Wadi Abo Khashaba and Wadi Om Yusr since that flood torrents also carry within sediments and boulders that damage infrastructure and urban areas. In 1996 a storm event hit the area and caused floodings that destructed many parts of the coastal highway.

Figure (12) Ras Garib after flash flood.

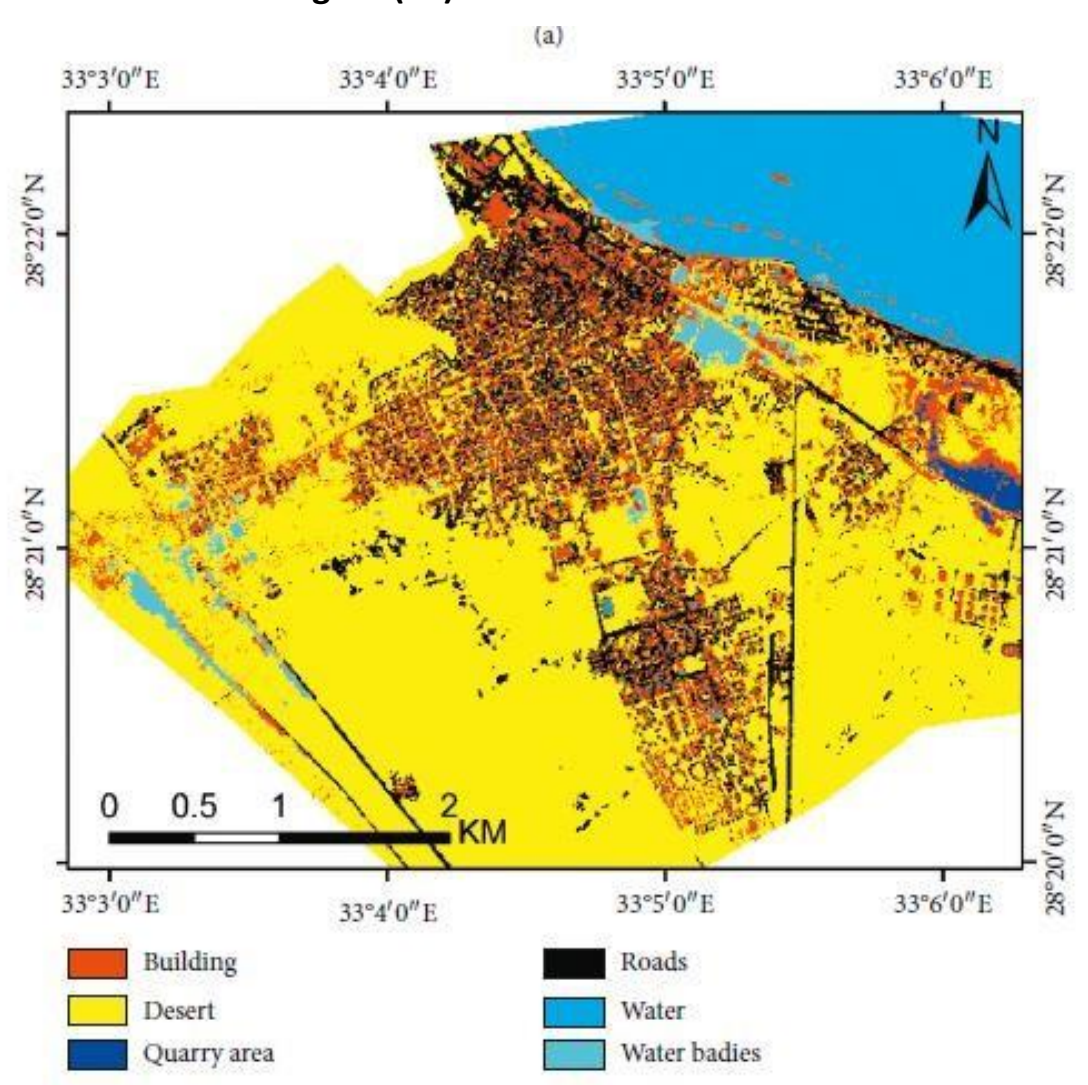


In 2016 the city of Ras Gharib was exposed to flash floods that caused massive destruction in the infrastructure and destroyed many homes and facilities. The amount of 130 million $\mathrm{m}^{3}$ of runoff water hit the city (Elnazer, A. Aand others 2017). and the watercourse traveled at a speed of $22 \mathrm{~km} / \mathrm{h}$ before reaching the catchment area of Eldarb valley according to the government reports .

\subsubsection{Flood protection Gray infrastructure in Ras Gharib}

After the disaster in 2016, the central government planned a mega project for flood protection in the Red Sea Governorate with 397 million Egyptian bounds. The plan is to construct 3 artificial lakes, dirt barriers and 3 dams, and store them, in addition to 4 water barriers to complete the protection system in the Red Sea to avoid the disaster of Ras Gharib again in all cities of the governorate. The first lake has a capacity of $450,000 \mathrm{~m}^{3}$, while the storage capacity of the second lake reaches $570,000 \mathrm{~m}^{3}$, while the storage capacity of the third lake reaches $825,000 \mathrm{~m}^{3}$, with a total of two million cubic meters for the three lakes, pointing out that the Three Lakes project aims to protect Ras Gharib. Harvest water will be used to implement projects to feed the surrounding communities, in addition to increasing the underground tank. The total estimated cost of lakes up to 48 million Egyptian pounds. The total capacity of the three dams in Ras Gharib will be reached to 5 million cubic meters, contributing to the implementation of development projects as well as reducing the risks of torrents in Ras Gharib and Hurghada in the Red Sea Governorate.

That plans by the ministry of irrigation with cooperate with local government.

Despite the ambitious plan and implementation of a large part of it as fig (13) shows.

Figure (13) Flood Protection projects in Ras Gharib
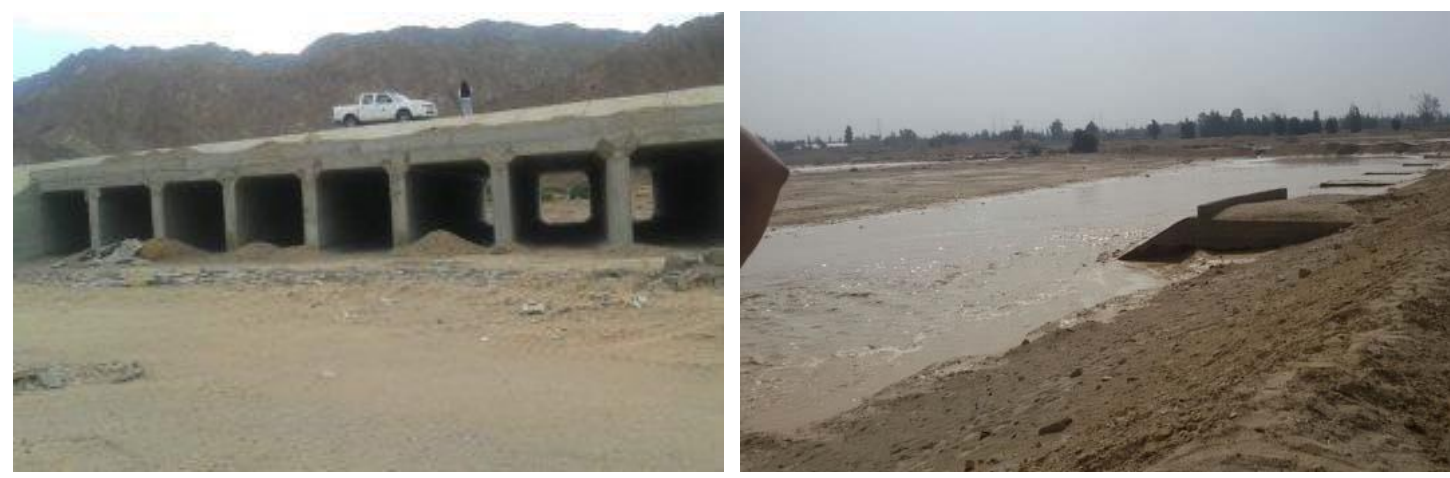

Source: https://www.youm7.com/story/2019/12/16/

\section{DISCUSSION}

The proposed plans and projects implemented on the ground illustrate the extent of understanding the seriousness of the threat of torrents on the city. But the plan relied on only two main objectives: protecting the city and collecting water without putting future plans for reuse water and urban development around these megaprojects. This is due to the responsibility of other entities for urban development plans, such as the Ministry of Housing and the Urban Planning Commission. This methodology dates back to a previous period where rainwater always a wasted resource it is treated in Egypt as a source of danger/ hazard and not an element that can be exploited. The constructed wetland technology is one of the economic solutions that can reduce high 
spending on gray infrastructure. And achieve high economic and urban returns as mentioned in international experiences (Haga O.Mohamed and Hanan O.A.( 2014). To achieve integration between existing projects and the concept of green infrastructure represented in the application of constructed wetlands.

The city and its environmental, urban and socio-economic surroundings must be treated as one unit in which systems integrate with institutions and stakeholders to transform the seasonal threat into a development goal and, sustainable applications. The problems that guide the current plan are the high cost and low return in addition to wasting large quantities of usable water. This is despite the lack of water in the city, and the entry of the whole region into water poverty level.

The researcher, in cooperation with a team of specialists and local authorities, set up an initial framework for the use of constructed wetlands to integrate with the existing gray infrastructure and planned in the future to achieve development goals and overcome previous problems and obstacles.

\section{CONSTRUCTED WETLAND AT RAS GARIB FRAMEWORK}

From theoretical and field study with the help of a research team from Modern University for Technology and Information, October University of Science and Arts in Egypt and cooperation with the South Company for Mining Services. A methodology has been created to redevelop and use the gray infrastructure that has been established and completed and put a framework to integrate this infrastructure with wetlands gardens to achieve the resilience city's concepts and sustainable development goals.

The stage of directing water to low points and the desert back is part of reducing the cost of facing the torrents in the city (Mohammed Sadek \& Xuxiang Li 2019) as shown in fig $(14,15)$. The first stage begins already by dams and of the construction of lakes. The second stage is water reuse and management in multi-functional landscape projects. Suggested three locations numbering in fig (14) according classification and analysis and depend on past studies.

This framework relies on three sub-frameworks that are integrated to achieve the comprehensive plan in development to suit the general plan of the country. 
Figure $(14,15)$ The proposed low areas for the formation of new constructed wetlands.
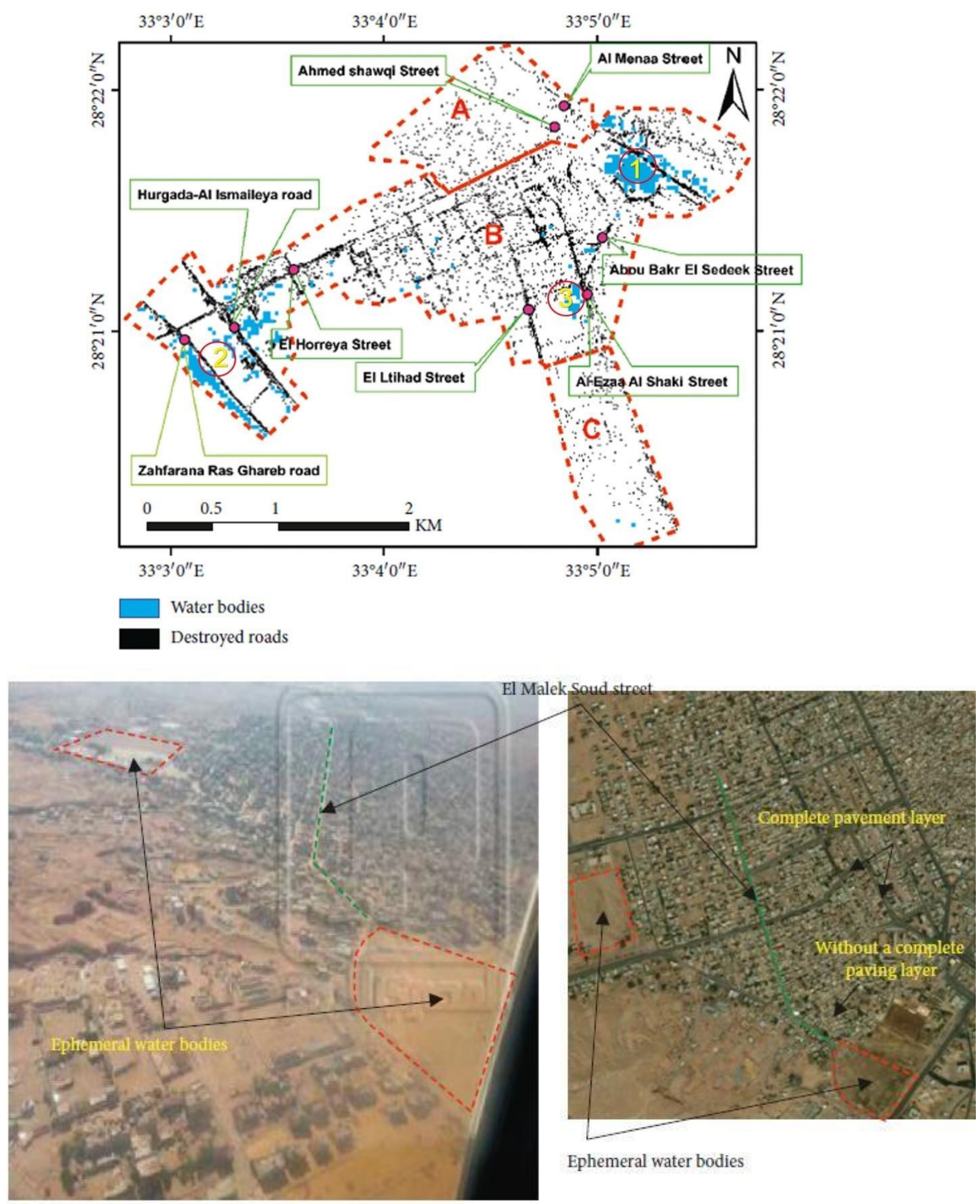

Ephemeral water bodies

Source: Mohammed Sadek \& Xuxing Li , 2019, Edited by researcher 


\subsection{Planning and Administrative Sub-Framework:}

This framework relies on setting an integrated plan in which all stakeholders, especially the concerned authorities and bodies: the Ministry of Irrigation for its responsibility for water sources, the Ministry of Housing for its responsibility for urban development, the Ministry of Agriculture, the Ministry of Environment and the Red Sea Governorate in addition to the local community in the city of Ras Gharib.

\subsection{Environmental Sub-Framework}

This framework contains a set of studies related to soil, geology and climate forecasts in addition to studies of groundwater, habitats and environmental impact. And study the expected scenarios from 2020 to 2030. Possibilities for intervention and targeted environmental benefits. By using the guidelines from National Center for Water Research for planting wetland in Egypt ( Salwa Abo Al ala 2017 ) With the diversity of the use of plants according to the classification used to purify the water. And in proportion to the dry seasons the region is going through. The formation of water lakes to store water in rainy seasons leads to sustainable use of water throughout the year if a good water management program is designed.

\subsection{Urban and Construction Sub- Framework}

This framework relies on the design and implementation of 3 wetland gardens around artificial lakes, in addition to designing a productive garden along the slope of the stream. These projects target investments of 100 million Egyptian pounds.

\section{CONCLUSION AND RECOMMENDATION}

Egypt faces many water challenges, especially water scarcity. Therefore, all available and future water resources must turn into strengths for the urban areas in which they are located. Therefore, we must shift in dealing with torrential water from a dangerous element to strength and contain it within the construction and reuse, which achieves the goals of the resilient city.

Ras Gharib is one of the cities that are most exposed to torrents annually. In the period between 2016 to now, a group of projects was established to protect the city from the risk of torrents. To transform this gray infrastructure from purely functional which is protection and water collection to multiple uses. These projects must be integrated with green infrastructure projects, the most important of which is our case in the constructed wetlands.

According to the theoretical and practical study, this technology is economical and easy to implement in the Egyptian climate and is environmentally and environmentally effective. Where an urban return is achieved and turns into an attractive element for cities and an economic resource.

Integrated development plans must be available in the elements of coordination and participation from all parties of the interest to achieve comprehensive development goals. Sometimes conflicts of interest and plans delay the development process but even negatively affect the Egyptian city. 
Academically, research and study projects that rely on the use of green technologies for urban development must be increased. Will Increasing practical experiences on a larger scale in Egyptian cities, which requires cooperation between more than one scientific and executive institution.

\section{REFERENCES}

A. Youssef and M. A. Hegab (2005)." Using Geographic Information Systems and Statistic for Developing A Database Management System of The Flood Hazard of Ras Gharib Area, Eastern Desert, Egypt.", Fourth International Conference on the Geology of Africa, Vol. (2), P-P 1-15 (NOV. 2005), Assiut, Egypt.

Abdulaziz, Saleh A. Alfayze and Mohamed Alfatih Hamadto (2007)," A Sustainable Water Resources Management Plan for Wadi Hanifa in Saudi Arabia". J. King Salld Univ. Vol. 19. Eng. Sci. (2). pp. 209-222. Riyadh, Saudi Arabia

Aga Khan Award for Architecture (2019) "Report of the Master Jury, Cycle of the Aga Khan Award for Architecture "

Ashraf M. Salama (2016) “Urban landscapes and future sustainable urban qualities in Middle Eastern cities", Contemporary Urban Landscapes of the Middle East. Taylor \& Francis.

Ashraf M. Salama and Anna Katharina Grichting (2015)," Edge, Center, and Spine: Exploring The Multi-Dimensionality of Contemporary Landscapes in Middle Eastern Cities " ArchnetIJAR, Volume 9 - Issue 2 - July 2015 - (113-136).

Azza Sirry (2018)," Alexandria: Development Challenges of a Costal Second City."Housing and Building National Research Center (HBRC), Cairo, Egypt

Chad Staddon and Others (2018), "Contributions of green infrastructure to enhancing urban resilience." Environment Systems and Decisions (2018) 38:330-338

D.P.L. Rousseau and others (2008)," Constructed wetlands for water reclamation", Desalination 218 (2008) 181-189, Elsevier.

Donald A.Hammer, (1992)," Designing constructed wetlands systems to treat agricultural nonpoint source pollution." Ecological Engineering Volume 1, Issues 1-2, March 1992, Pages 49-82, Elsevier.

Egyptian Environmental Affairs Agency, EEAA 2016, State of the Environment Report 2016

Elnazer, A. A., Salman, S. A., \& Asmoay, A. S. (2017). "Flash flood hazard affected Ras Gharib city, Red Sea, Egypt: a proposed flash flood channel." Natural hazards, 89(3), 1389-1400.

Faith Ka Shun Chana and others (2018)," Sponge City" in China-A breakthrough of planning and flood risk management in the urban context", Land Use Policy, https://doi.org/10.1016/j.landusepol.2018.03.005

Haga Osman Mohamed and Hanan Osman Ali(2014). "Efficiency of Constructed Wetlands in Arid Regions." International Journal of Engineering Innovation \& Research. Volume 3, Issue 5, 597-306

HannahWrigh(2011), "Understanding green infrastructure: the development of a contested concept in England.", Local Environment Vol. 16, No. 10, November 2011, 1003-1019, Taylor \& Francis.

Hesham Ezz, Muhammad Gomaah and Mohamed Abdelwares (2019) "Groundwater Recharge for Ras Gharib Region, Egypt." Journal of Geoscience and Environment Protection, 7(04), 202.

http://www.redsea.gov.eg/t/Ras\%20Gharib/RasGharib.aspx 
Josh Foster, Ashley Lowe and Steve Winkelman (2011), "The Value of Green Infrastructure for Urban Climate Adaptation.", Center for Clean Air Policy, Washington, USA

KongjianYu ( 2015)., "Deep Forms: Nature-Based Solutions." , Peking University College of Architecture and Landscape and Turenscape, Beijing, China.

M.N. Hegazy a, , H.A. Effat b (2010). "Monitoring some environmental impacts of oil industry on coastal zone using different remotely sensed data." , The Egyptian Journal of Remote Sensing and Space Sciences (2010) 13, 63-74

Mahmod A., Abdel Hamid A., (2015)," Monitoring human intervention in the geomorphology of the Red Sea coastal zone (between Suez and Marsa Alam) using GIS and remote sensing data", Arabic geographical magazine, issue 46

Margaret Greenway (2005)," The role of constructed wetlands in secondary effluent treatment and water reuse in subtropical and arid Australia." Ecological Engineering 25 (2005) 501-509, Elsevier.

Marijke Ronduite(2017)."Constructed Wetlands for Wastewater Treatment and Reuse in Northern -Thailand". Utrecht University

Mohammad al-Asad and Yldrm Yavuz (2004), "Wadi Hanifa Development Plan." Riyadh, Saudi Arabia

Mohammed El Bastawesy Kevin White and Ayman Nasr (2009) “Application of remote sensing and GIS for the mitigation measures for flash floods affecting the urban areas in Egyp", Hydrol. Process. 23, 1359- 1368 (2009), Wiley InterScience

Mohammed Sadek and Xuxiang Li (2019) "Low-Cost Solution for Assessment of Urban Flash Flood Impacts Using Sentinel-2 Satellite Images and Fuzzy Analytic Hierarchy Process: A Case Study of Ras Ghareb City, Egypt." Hindawi Advances in Civil Engineering Volume 2019, Article ID 2561215, 15.

Mohamed Abd El- Rahman Fawzi and Others ( 2013), Egypt's National Strategy for Adaptation to Climate Change And Disaster Risk Reduction

R.B.E. Shutes, D.M. Revitt, I.M. Lagerberg and V.C.E. Barraud ( 1999)."The design of vegetative constructed wetlands for the treatment of highway runoff." The Science of the Total Environment 235_1999. 189]197, Elsevier.

R.S. de Groot et al. (2010) "Global estimates of the value of ecosystems and their services in monetary units." , Ecosystem Services, Volume 1, Issue 1, July 2012, Pages 50-61, Elsevier.

Red Sea Governorate (2019), "Ras Gharib overview"

Salwa Abo Al Ala( 2017) , Guidelines To improve the water quality in the path of drains using Water weeds, Water Canal Maintenance Research Institute National Center for Water Research, Cairo ,Egypt

Shereif H. Mahmoud (2014), "Investigation of rainfall-runoff modeling for Egypt by using remote sensing and GIS integration." Catena 120.111-121, Elsevier.

Sohair I. Abou-Elela Ekhnawy, Magdy T. Khalil \& Mohamed S. Hellal ( 2017), "Factors Affecting the Performance of Horizontal Flow Constructed Treatment Wetland Vegetated with Cyperus Papyrus for Municipal Wastewater Treatment." , International Journal of Phytoremediation, DOI: 10.1080/15226514.2017.1319327, Taylor \& Francis.

Sophie Moinier (2013)," Constructed Wetlands redefined as Functional Wetlands." 1202415047-GEO-0001, Deltares 
The general institution of urban planning (2017) "Urban development strategy of waterfronts, red sea." , Cairo, Egypt

Urrbra Wetland Border scale and water catchment network http://www.urrbraewetlandlc.org/data-photos-and-maps.html

Urban Planning Authority, Ministry of Housing (2017),Urban Development Strategy for Waterfronts, Red Sea Coast Range.

US EPA, OW.(2015). "What is Green from US EPA Infrastructure?",US EPA. Retrieved November 2019, website: https://www.epa.gov/greeninfrastructure/what green infrastructure/.

Wael al-Samhouri and Mashary al-Naim (2007)," Wadi Hanifa Wetlands.", Arriyadh Development Authority, Riyadh, Saudi Arabia 